\title{
Fractionation of Snake Fruit Seeds Pondoh for Development of Anemia Treatment
}

\author{
Kiki Natasia ${ }^{1}$, Dono Indarto ${ }^{1,2,3}$, Brian Wasita ${ }^{1,4}$ \\ \{kikynatashaa@gmail.com, dono@staff.uns.ac.id, brianwasita@yahoo.com\} \\ ${ }^{1}$ Postgraduate of Nutrition Sciences, Universitas Sebelas Maret, Surakarta, ${ }^{2}$ Department of \\ Physiology, Faculty of Medicine, Universitas Sebelas Maret, Surakarta, ${ }^{3}$ Biomedical \\ Laboratory, Faculty of Medicine, Universitas Sebelas Maret, Surakarta, ${ }^{4}$ Department of \\ Anatomical Pathology, Faculty of Medicine, Universitas Sebelas Maret, Surakarta
}

\begin{abstract}
In a recent study, snake fruit seed (SFS) flour was found to enhance haemoglobin levels in a rat model of anemia. Still, it increases leucocyte number and its differential count. The purpose of this study was to fractionate SFS Pondoh and to analyze phytochemical compounds in SFS fractions. Simplicia of SFS was separated into lipid, water, and organic fractions using tetrahydrofuran, methanol and ethyl acetate reagents, and then dried using a vacuum evaporator. Chemical components in the SFS fractions were analyzed using gas chromatography-mass spectrophotometry (GC-MS). We got $77.8 \%, 16.5 \%$, and $7.5 \%$ fractions of water, organic, and lipid. The water fraction contained 13 active compounds with 19 to 22 min retention time (RT). The organic fraction also had 13 active compounds with 19 to $29 \mathrm{~min}$ RT. The last lipid fraction contained 15 active compounds with 3 to 25 min RT. In conclusion, SFS Pondoh generates the highest water fraction, followed by organic and lipid fractions.
\end{abstract}

Keywords: Snake Fruit Seed, Fractionation, Phytochemical, Anemia

\section{Introduction}

Snake fruit (Salacca edulis Reinw.) is a domesticated Indonesian plant that grows in a variety of locations [1]. Snake fruit Pondoh is a prominent variety of snake fruit that found in Donokerto village, Turi district, Sleman Regency, Yogyakarta. However, snake peels and seeds become waste and are get ride to the land [2]. The utilization of snake fruit seeds has become necessary because the snake seeds occupy $30 \%$ of the whole snake fruit [3].

From recent studies conducted by Melati et al. (2019) and Ristanti et al. (2019), they have successfully extracted snake fruit seed (SFS) flour with ethanol solvent, and it was administrated to female wistar rats with anemia. Administration of $3.5 \mathrm{~g} / \mathrm{kg}$ body weight SFS for 28 days improves hemoglobin $(\mathrm{Hb})$ levels from moderate anemia to normal condition in 
female wistar rats with anemia. However, the increased $\mathrm{Hb}$ levels in those rats are also followed by the increased number of leukocytes and lymphocytes, which probably results from various secondary metabolites [4, 5]. A drop in iron levels can hamper erythrocyte synthesis, resulting in an increase in leucocytes. Because hypoferremia keeps the quantity of iron available for other metabolic demands during infection, glucocorticoid activity rises, causing the release of numerous nucleated leukocytes from the bone marrow to be blocked. In addition, inflammatory cytokines have a direct effect on the immune system $[6,7,8]$. In comparison, lymphocytes are associated with virus infections and hypersensitivity reactions. But it has not been confirmed that a hypersensitivity reaction caused the increase in lymphocytes due to the administration of Fe and SFS extract supplements, which were considered foreign bodies, or due to increased stress from cage conditions other stress factors [5]. Therefore this study aimed to fractionate SFS Pondoh and analyze phytochemical compounds in SFS fractions to minimize secondary metabolites in lipid fraction. The method used to separate secondary metabolites such as phenols, flavonoids, and tannins has $229.27 \pm$ $\mathrm{g} / \mathrm{mL}$ IC50 for antioxidant activity in SFS flour [3].

\section{Research Methods}

\subsection{Fractionation of SFS}

Snake fruit seeds produced by a home food company in Donokerto village, Turi district, Sleman Regency, Yogyakarta, were used as raw materials in this study. All of the seeds were air-dried in direct sunlight and then dried for 8 hours in a cabinet dryer and 90 minutes in an oven. To make simplicia, dried snake fruit seeds were crushed and sieved. The simplicia was then extracted to distinct lipid, water, and organic fractions using tetrahydrofuran, methanol, acetic acid, hexane, and or ethyl acetate reagents, as previously described. We made a minor change to a study done by Tang and colleagues (2018) [9]. SFS Simplicia was first dissolved in a tetrahydrofuran solution and centrifuged at 4,200 $\mathrm{g}$ for 10 minutes at $370 \mathrm{C}$ in a water bath. To collect the supernatant as a lipid-soluble fraction, the extraction was repeated using the same reagent. At $37^{\circ} \mathrm{C}$ for 30 minutes in a water bath, collected residues were dissolved in 50: 3.7: 46.3 volume/volume methanol-acetic acid-water solutions. The supernatant was collected after centrifugation, and the residue was re-extracted to get a water-soluble fraction. The leftover residue was resuspended in a buffer solution containing $2 \mathrm{M} \mathrm{NaOH}$, ten $\mathrm{mM}$ EDTA, and one percent ascorbic acid, and then acidified to $\mathrm{pH} 26 \mathrm{M} \mathrm{HCl}$ solution at $37^{\circ} \mathrm{C}$ in a water bath for 30 minutes. To remove fatty acids, the mixture was extracted twice with $5 \mathrm{~mL}$ n-hexane, then twice with $5 \mathrm{~mL}$ diethyl ether and $5 \mathrm{~mL}$ ethyl acetate mixtures. After 10 minutes of centrifugation, the supernatant was collected as the organic-soluble fraction. A vacuum evaporator was used to dry the snake fruit seed filtrate, and the extract was then preserved in a refrigerator until further examination. The formula was used to compute the yield of SFS fractions:

Yield $=\frac{\text { Weight of fraction }(g)}{\text { Weight of simplicia }(g)} \times 100 \%$

\subsection{Identification of Chemical Compounds in the SFS Fractions}

The method reported by Javadi et al. (2014) was modified slightly for the GC-MS analysis of SFS fractions. A DB 5MS column (250 m inner diameter and $250 \mathrm{~m}$ film thickness $)$ 
containing 5\% phenyl methyl siloxane was used to examine the samples, which was connected to an Agilent 5973 quadrupole and mass selective detector (Agilent, Santa Clara, United States) [10]. In a nutshell, 1 liter of sample was fed into the GC-MS, which was heated to $180^{\circ} \mathrm{C}$ for 10 minutes before increasing to $20^{\circ} \mathrm{C} /$ minute for 5 minutes. The next step was to increase the temperature at $315^{\circ} \mathrm{C}$ with $30^{\circ} \mathrm{C} /$ minute for 10 minutes so that the total running time was 30.16 minutes. The mass spectrum was set up at a $50-550 \mathrm{~m} / \mathrm{z}$ specific range. The peak and retention times of identified compounds were compared and matched to the peak spectra from the NIST14 standard library.

\section{Results and Discussion}

\subsection{The yield of SFS Fractions}

This present study first documented the SFS fractionation using a Tang et al. method [9].

Table 1. The yield of SFS Fraction

\begin{tabular}{lccc}
\hline & Simplicia $(\mathrm{g})$ & Fraction $(\mathrm{g})$ & Yield $(\%)$ \\
\hline Water Fraction & 133 & 103.6 & 77.8 \\
Organic Fraction & 133 & 22 & 16.5 \\
Lipid Fraction & 133 & 10 & 7.5 \\
\hline
\end{tabular}

Table 1 indicated that the yield of the SFS water fraction (77.8\%) was higher than the yield of SFS organic (16.5\%) and lipid fraction $(7.5 \%)$. The more significant result produced, the more efficient the treatment is applied without neglecting other properties. Based on the yield of SFS fractionation, it can be assumed that the active compounds in the water fraction are more than the lipid and organic fractions. In our present study, Dewatisari et al. (2017) study that a high yield value indicates the high number of active compounds within the extract. They were extracted using simplicia of sansevieria (Sansevieria cylindrica and Sansevieria trifasciata) with a combination of Hexane, Acetone, and Ethanol solvents. However, their method yielded $7.89 \%$ S.trifasciata extract, higher than $6.79 \%$ S.cylindrica [11]. Therefore, the water SFS fraction potentially becomes an alternative supplement for anemia.

\subsection{Bioactive Chemical Compounds in SFS Fractions}

Figure $1 \mathrm{~A}-\mathrm{C}$ showed that peaks and retention times were detected in water, organic, and lipid SFS fractions. In water and organic particles, we got many primes, and it wasn't easy to separate from each other. At the same time, we observed some of the highest peaks in the lipid fraction with different retention times. There were 18.67, 19.90, 20.29, 22.81, and 24.19 minute retention times. 


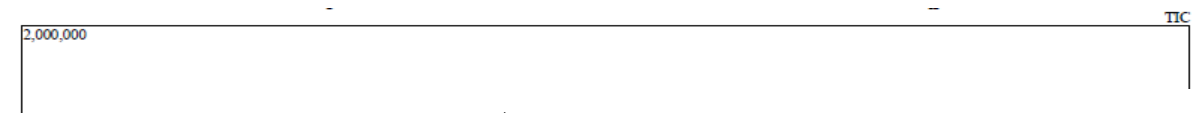

A. Chromatogram of Water Fraction

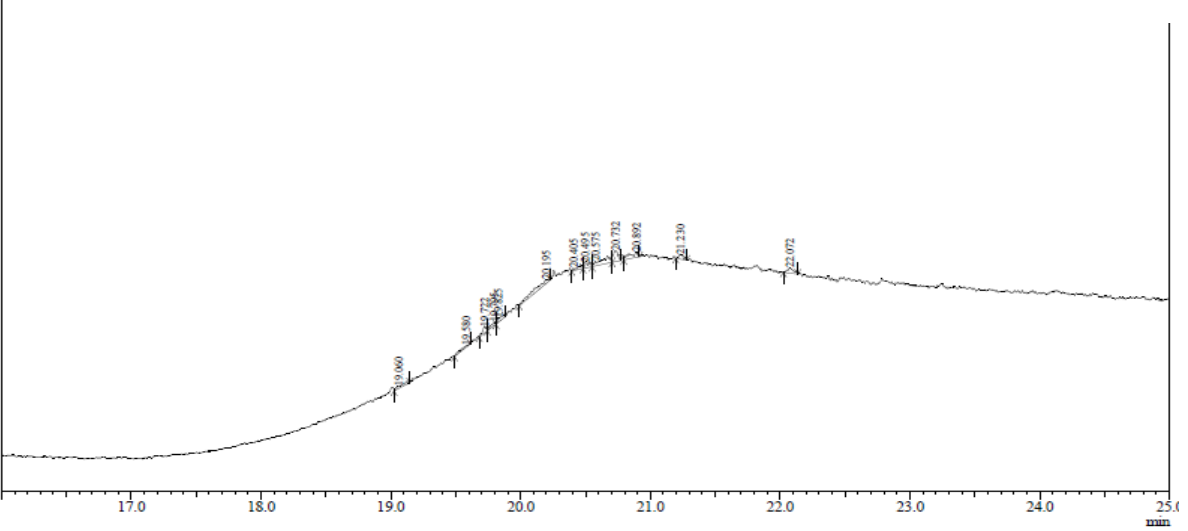

B. Chromatogram of Organic Fraction

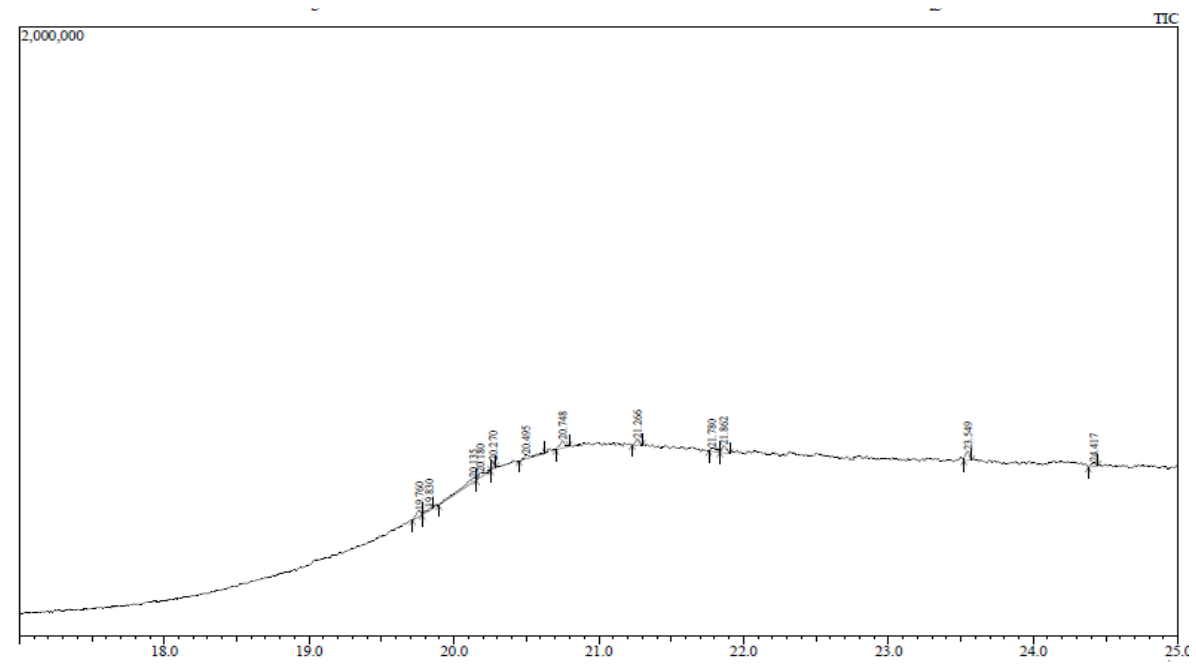

C. Chromatogram of Lipid Fraction

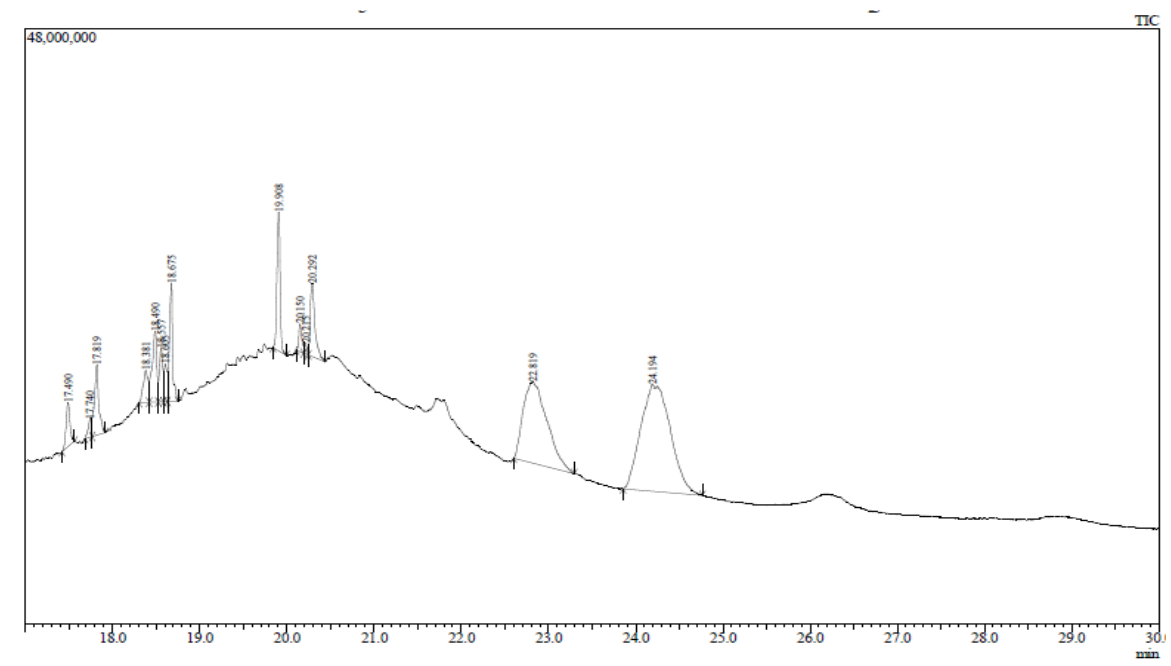


Figure 1. Chromatogram of Water, Organic and Lipid SFS Fractions

The most active compounds contained in each fraction can be seen in the following table:

Table 2. The Highest Bioactive Compounds were Detected in Water, Organic and Lipid SFS Fractions

\begin{tabular}{|c|c|c|c|}
\hline Fraction & Compounds & $\begin{array}{l}\text { Retention Time } \\
(\mathrm{sec})\end{array}$ & $\begin{array}{c}\text { Area } \\
(\%)\end{array}$ \\
\hline \multirow{5}{*}{$\begin{array}{c}\text { Water } \\
\text { Fraction }\end{array}$} & $\begin{array}{l}\text { 2H-3,9a-Methano-1-benzoxazine, octahedron- } \\
\text { 2,2,5a,9-tetramethyl-, [3R- } \\
\text { (3.alpha.,5a.alpha.,9.alpha.,9a.alpha.)]- (CAS) }\end{array}$ & 20.19 & 17.42 \\
\hline & $\begin{array}{l}\text { 14.alpha.-Cheilanthes-13(14)-enic Methyl } \\
\text { Ester }\end{array}$ & 20.57 & 15.37 \\
\hline & $\begin{array}{c}\text { 1H-Purin-6-amine, [(2-fluorophenyl)methyl]- } \\
\text { (CAS) }\end{array}$ & 20.73 & 11.76 \\
\hline & (Trifluoromethoxy)nitrobenzene & 20.89 & 8.99 \\
\hline & 6-Heptadecyl-5,6-dihydro-2H-pyran-2-one & 20.49 & 6.98 \\
\hline \multirow{5}{*}{$\begin{array}{l}\text { Organic } \\
\text { Fraction }\end{array}$} & $\begin{array}{l}\text { 2,2'-Aminobis(1,3,5-triazine), 4,4'6,6'- } \\
\text { tetra(dimethylamino)- }\end{array}$ & 20.13 & 18.58 \\
\hline & SILICONE OIL & 20.74 & 9.76 \\
\hline & $\begin{array}{l}\text { 1,4-Epoxynaphthalene-1(2H)-methanol, 4,5,7- } \\
\text { tris(1,1-dimethylethyl)-3,4-dihydro- (CAS) }\end{array}$ & 23.54 & 9.50 \\
\hline & SILIKONFETT & 21.86 & 8.29 \\
\hline & SILICONE GREASE, SILICONFETT & 20.18 & 7.99 \\
\hline \multirow{5}{*}{$\begin{array}{l}\text { Lipid } \\
\text { Fraction }\end{array}$} & Tridecanedial & 24.19 & 40.87 \\
\hline & HAHNFETT & 22.81 & 24.96 \\
\hline & $\begin{array}{l}\text { 2,6,10,14,18,22-Tetracosahexaene, } \\
2,6,10,15,19,23 \text {-hexamethyl- (CAS) }\end{array}$ & 19.9 & 5.65 \\
\hline & $\begin{array}{l}\text { 1,2-Benzenedicarboxylic acid, bis(2- } \\
\text { Ethylhexyl) ester (CAS) }\end{array}$ & 18.67 & 5.02 \\
\hline & Cholest-5-en-3-ol (3.beta.)-, acetate (CAS) & 20.29 & 4.39 \\
\hline
\end{tabular}

Based on the NIST14 database library, we got the five highest proportions of chemical compounds in water, organic, and lipid SFS fractions (Table 2), and all chemical compounds belong to secondary metabolites. In water and organic SFS fraction, the highest proportion of chemical compound was 2H-3,9a-Methano-1-benzoxazine,octahedron-2,2,5a,9-tetramethyl-, [3R- (17.42\%) and 2,2'-Aminobis(1,3,5-triazine), 4,4'6,6'-tetra(dimethylamino)- (18.58\%) compounds which functions as anti-microbe, anti-inflammation [12]. Two other chemical compounds in the water SFS fraction were 14.alpha.-Cheilanthes-13(14)-enic Methyl Ester $(15.37 \%)$ and 1H-Purin-6-amine, [(2-fluorophenyl)methyl]- (CAS) (11.76\%) compounds with an antibacterial activity and anti-cancer [13]. The remaining chemical compounds in the water SFS fraction and four chemical compounds in the organic SFS fraction had less than 5\% proportion. However, the lipid SFS fraction had different proportions and chemical compounds from the water and organic SFS fractions, which were Tridecanedial $(40.87 \%)$ and HAHNFETT (24.96\%) with anti-microbial and anti-inflammatory activities [12].

We have reported that chemical analysis and fractionation of SFS were firstly performed in this present study. Comparing to the Saleh et al. (2018) study, we similarly evaluated the chemical compounds in snake fruits, but we fractionated the SFS extract while the Saleh study extracted snake fruit peels. Primary metabolites were identified in ethanol extract of snake 
fruit peels: sucrose (17.07\%), D-fructose (12.05\%), and D-(-)-Tagatose $(11.05 \%)$, while secondary metabolites of snake fruit peels were phenolic, phytosterol, fatty acid, and organic acids. In addition, ethanol extract of snake fruit peels has high antioxidant and $\alpha$-glucosidase inhibitory properties, indicating health benefits. Phenolic compounds reduce digestive enzymes and help oxidize fats of the body due to their thermogenic properties [14]. Based on the literature, searches documented that the identified compounds have reported various biological activities, considered antioxidant, anti-inflammatory, anti-bacterial, and antidiabetic [15].

\section{Conclusion}

Fractionation of SFS using hexane and ethyl acetate solvents yields a higher water fraction followed by organic and lipid fractions. From chemical analysis, the three SFS fractions have different chemical compounds and proportions. Further investigation is required to determine chemical compound's activity and their beneficial effects on the human body.

Acknowledgments. The authors would like to express their gratitude to the Indonesian Minister of Research, Technology, and Higher Education for providing a research funding for a thesis in 2020. We also appreciate the chemical testing of our SFS simplicia and fractions by the Integrated Laboratory of Food and Nutrition, Gadjah Mada University, Yogyakarta, and the Chemistry Laboratory, Faculty of Life Sciences, Semarang State University, Ahmad Dahlan University, and Setia Budi University, respectively.

\section{References}

[1] Suskendriyati H, Wijayati A, Hidayah N and Cahyuning D. Study of Morphology and Relationship between Salak Pondoh (Salacca Zalacca (Geert.) Voss.) Varieties in the Sleman Highlands. Biodiversity. 2000; 1(2):59-64:1412-033x.

[2] Latuconsina NH, Fatimawali and Citraningtyas G. Uji Efektivitas Diuretik Ekstrak Etanol Biji Salak (Salacca Zalacca Varietas Zalacca (Gaert.) Voss) Pada Tikus Putih Jantan Galur Wistar (Rattus Norvegicus). Pharmacon. 2014; 3(3):176-181.

[3] Werdyani S, Jumaryatno P and Khasanah N. Antioxidant Activity of Ethanolic Extract and Fraction of Salak Fruit Seeds (Salacca zalacca (Gaertn.) Voss.) Using DPPH (2,2-diphenyl-1picrylhydrazyl) Method. Eksakta Jurnal Ilmu-Ilmu MIPA. 2017.

[4] Denis M. The Effect of Giving Salak Seed Extract on Body Weight, Hematological Profile, Serum Ferritin and Transferrin Levels in Anemia Model Mice. Surakarta: Thesis S2 Nutrition Science Postgraduate UNS Surakarta. 2019.

[5] Ristanti IK. Effect of salak seed extract on body weight, hematological profile, levels hepcidin and matriptase-2 in the rat model of anemia. Surakarta: Thesis S2 Nutrition Science Degree UNS Surakarta. 2019.

[6] Singh K. Leucocyte Count in Anemia. Indian J Physiol Pharmacol. 2010; 54:85 - 8.

[7] Samanta P and Senapati LK. Association of Nutritional Anemia with Leucocyte and Platelet Counts in Odisha. Nail J Physiol Pharm Pharmacol. 2018; 8:526 - 29.

[8] Ganz T. Iron and Infection. Int J Hematol. 2017; 107:7 - 15.

[9] Tang G-Y, Zhao C-N, Liu Q, Feng X-L, Xu X-Y, Cao S-Y, Meng X, Li S, Gan RY and Li H-B. Potential of Grape Wastes Natural Source of Bioactive Compound. Molecules. 2018; 23:2598. 
[10] Javadi N, Abas F, Abd Hamid A, Simoh S, Shaari K, Ismail IS, et al. GC-MS-based Metabolite Profiling of Cosmos caudatus Leaves Possessing Alpha-glucosidase Inhibitory Activity. J Food Sci. 2014; 79(6):1130.

[11] Dewatisari WF, Rumiyanti L, and Rakhmawati I. Rendemen and Phytochemical screening using leaf extract of Sansevieria Sp. Jurnal Penelitian Pertanian Terpadu. 2017; 17(3):197-202.

[12] Mastuti and Handayani. Senyawa Kimia Penyusun Ekstrak Ethyl asetat dari Daun Pisang Batu dan Ambon Hasil Distilasi air Tangerang - Banten. Universitas Pelita Harapan. 2014.

[13] Sari P. Aktivitas Antibakteri Ekstrak Etanol Dan Heksana Daun Bangle (Zingiberis cassumunar Roxb) Terhadap Escericia Coli Dan Staphylococus Aureus Yogyakarta. Yogyakarta: Universitas Atmajaya Yogyakarta Fakultas Teknobiologi. 2016.

[14] Saleh MSM, Siddiqui MJ, So'ad SZM, Murugesu S, Khatib A, and Rahman MM. Antioxidant and $\alpha$-Glucosidase Inhibitory Activities and Gas Chromatography-Mass Spectrometry Profile of Salak (Salacca zalacca) Fruit Peel. Extract Pharmacognosy Research. 2018; 10(4).

[15] Ramsden CE, Zamora D, Leelarthaepin B, Majchrzak-Hong SF, Faurot KR, Suchindran CM, et al. Use of Dietary Linoleic Acid for Secondary Prevention of coronary Heart Disease and Death: Evaluation of Recovered Data From the Sydney Diet Heart Study and Updated Meta-Analysis. BMJ. 2013; 346:8707. 